Okeford Fitzpaine, near Shillingstone Station, Dorsetshire. The specimens indicate two well-marked horizons: (r) the zone of Hoplites (Ammonites) interruptus, with beds ig feet in depth, and (2) the Acanthoceras (Ammonites) mammillatum zone, measuring 5 feet in thickness. The $H$. interruptus beds consist of a dark grey, micaceous and sandy clay, and therefore more closely resemble the Lower Gault of Black Venn, near Lyme Regis, than the typical argillaceous deposits at Folkestone. These beds have yielded about twenty-eight described species belonging to the groups Pisces, Cephalopoda, Gasteropoda, Lamellibranchiata, and Plantæ. Among the specimens obtained from the $A$. mammillatum zone, besides the Ammonite here alluded to, are specimens of Pleuromya plicata, Cucullea carinata, Exogyra sinuata, and enormous examples of Ostrea leymeriei. For a more detailed notice of this discovery at Okeford Fitzpaine see the Geological Magazine, I 896, p. 198. A fine series of Inferior Oolite Gasteropoda, mainly collected by Mr. Henry Monk and others, from the classic quarries (Halfway House, Oborne, Stoford, Bradford Abbas, etc.) in the neighbourhood of Yeovil, were next examined. Such genera as Neritopsis, Amberleya, Pleurotomaria, and Cryptaulax were pointed out as exhibiting most beautiful examples of testaceous sculpturing.

Some choice Carboniferous Lamellibranchs. Streblopteria sublobata, were next alluded to on account of the original colour marking being retained in their shells.

Finally, attention was called to several examples of the genus Oriostoma $(O$. funatum and $O$. sculptum $)$, obtained from the Wenlock Limestone of Dudley, in a fine state of preservation, most of them exhibiting the concentrically ornamented operculum in situ.

\title{
EXCURSION TO CHESHAM AND COWCROFT (TYLER'S HILL).
}

Saturday, April 3 RD, I897.

Director: UpField Green, F.G.S. Excursion Secretary: H. A. Allen, F.G.S.

(Report bv The DrReCTOR.)

THE party assembled at Baker Street Station, and travelled to Chesham by the 1.37 p.m. train. On arrival, the Director led the way across the fields on the east side of the river Chess to the brickfields on the hill known as Cowcroft, or Tyler's Hill. The JULY, I897.] 
upper part of the hill is composed of Eocene Beds, which form a small outlier about three-quarters of a mile long.by half a mile in width, and on them there is a small capping of drift.

Three sections were visited, two on the east and one on the west side of Cowcroft. On arrival at the first section, the Director made a few observations on the geology of the locality. He remarked that Cowcroft was one of a line of Eocene outliers which run parallel to the northern boundary of the main mass of the Tertiary strata, that is, in a north-east and south-west direction; and he thought they were all probably due to a line of slight change of dip, which passed through Woodcote Common, near Goring, Nettlebed Hill, Turville Common, Lane End, Tyler's Hill, and Bennet's End. This had been suggested by Mr. Whitaker, ${ }^{*}$ and evidence in support of this contention had been pointed out by the Director on the occasion of the Excursion to Wendover, May 14 th, $1892 .+$

These outliers are nearly always capped by pebble gravel, the Westleton Shingle of Professor Prestwich, and are frequentiy connected with trough faults whereby Tertiary Beds were protected from denudation.

In the first section, at the north-east corner of the brickfield, the whole of the Reading Beds were exposed, about 25 feet in thickness, the lower portion consisting of grey, mottled, laminated sandy clay, the upper of very white sand, indurated in parts. At the base is a layer of about 6 inches of green-coated unwater-worn flints and pebbles, reposing on a level surface of chalk, which has been excavated to a depth of about i 5 feet, but presents no features of importance. This section is capped by the Basement Bed of the London Clay which is $3-5 \mathrm{ft}$. thick, but owing to the recent heavy rains could not be examined.

The second section, at the S.E. corner of the brickfield, shows the Chalk fretted away in pinnacles, two of which were visible. These pinnacles are invested with a dark layer, consisting of unworn flints in clay mingled with pebbles and broken shells, surmounted by Brick-earth, which thickens towards the S., extending downwards far below the level of the base of the pinnacles. In the upper portion of the Brick-earth masses of conglomerate and irregular layers of flint and quartz pebbles are found, the latter parallel to the top of the Chalk, though not resting upon it. Mr. Monckton suggested that the position of the Brick-earth was due to a large pipe or swallow hole in the Chalk into which a mass of drift had sunk.

The third section is at the S.W. corner of the outlier, and shows about $\mathrm{I}_{5} \mathrm{ft}$. of Woolwich and Reading Beds, the lower portion of these and the junction with the Chalk not being 
visible. These beds consist here of $7-8 \mathrm{ft}$. of Buff Sands, with irregular pipe-clay partings passing upwards into bright-red mottled sands $4 \mathrm{ft}$., and another $4 \mathrm{ft}$. of white sand, mottled red. Above these occurs the Basement Bed of the London Clay, consisting of a very well-marked line of flint pebbles about 6 inches in thickness, in which Lamna teeth were found. Covering this, there is about $\mathbf{I} 2 \mathrm{ft}$. of evenly-stratified laminated sandy clay, with a more or less continuous line of flint pebbles, and from this bed many large calcareous blocks containing fossils had been extracted. None of these were, however, seen in sitû on this occasion. The following fossils were identified :

Ditrupa plana, Sow.

Cardium laytoni, Mor.

Cosp.

Cytherea sp.

Glycimeris mutupiensis.

Nucula?

Panopeca intermedia, Sow.

Pectunculus brevirostris, Sow.

Fusus ficulneus, Desh.

, sp.

Melania sp.

Natica sp.

Pyrula sp.

Leaving Cowcroft, the party proceeded in a south-westerly direction across the valley of the Chess to a chalk-pit at Aldridge's Dell. In this pit the Chalk Rock is seen. It does not, however, appear to be very fossiliferous; but after a time one of the members found a moderately good specimen of Terebratula semiglobosa. The Director had, some few days before the excursion, found Vermicularia, Rhynchonella reedensis, Eth., Arca, Limopsis, Lima spinosa, Sow., and Trochus. The party then returned to Chesham, where they partook o. an excellent tea at the Chess Vale Hotel. After tea Mr. Monckton proposed a vote of thanks to the Director, which was carried by acclamation, and the party returned to London.

It may be of interest to note that the only previously recorded excursion of the Association to Tyler's Hill took place on May 18th, 1878, under the direction of Dr. (now Sir) John Evans and Mr. Hopkinson. It was a half-day excursion, and as there was at that time no railway to Chesham the party travelled to Boxmoor Station and drove from there to Tyler's Hill. 


\title{
REFERENCES.
}

Geological Survey Map, Sheet 7 (Drift Edition, I871). Price 18s. 6d.

Geological Súrvey Index Map, Sheet I2. Price 2s. 6d.

Ordnance Survey Map.(New Series), Sheet $23^{8}$.

1854. Prestwich, J.- "On the Strata between the London Clay and the Chalk, etc." Quart. Fourn. Geol. Soc., vol. x, p. 90.

I878. Hopkinson, J.- "Excursion to Tyler's Hill, Chesham." Record of Excursions, p. 228.

1889. WhItAKER, W.- "Geology of London." Mem. Geol. Survey, vol. i, P. I94.

I890. PRESTWICH, J.- "Relation of the Westleton Beds, etc." Quart. Fourn. Geol. Soc., vol: xlvi, p. I 39 .

I896. SALTER, A. E.- " "Pebbly Gravel' from Goring Gap to the Norfolk Coast." Proc. Geol. Assoc., vol. xiv, p. $3^{89}$.

\section{EXCURSION TO AYLESBURY, HARTWELL, AND STONE.}

\author{
SATURday, APRil IOTh, 1897. \\ Directors : A. M. Davies, B.Sc., F.G.S., and \\ Percy Emary, F.G.S. \\ Excursion Secretary : H. A. Allen, F.G.S. \\ (Redort by THE DIRECTORS.)
}

ABout twenty-three members assembled at Aylesbury (Metropolitan Railway) shortly after 3 p.m., and were led without delay along a field-path to Locke's clay-pit, on the Thame road, about a mile and a quarter out of Aylesbury. Here Mr. Davies briefly explained the objects of the excursion. It was nearly ten years, he said, since the Association had visited this district, which was probably new ground to many present. To the east and south the Chalk escarpment of the Chilterns was conspicuous. The vale at the foot of it was marked on the geological map as occupied mainly by Gault and Kimeridge Clays, between the outcrops of which two clays came an apparently irregular and discontinuous series of patches mapped as Portland Sand, Portland Stone, Purbeck, and Lower Greensand. The ground on which they were then standing was mapped as Kimeridge Clay, but the fossils which had made this pit famous indicated a higher horizon than the highest proper Kimeridgian, and though for mapping purposes it was impossible to separate it from Kimeridge Clay, it was better to speak of it as Hartwell Clay, and to include it, as Mr. JuLv, I897.] 